\title{
Seismic performance of existing water tank after condition ranking using non-destructive testing
}

\author{
Chittaranjan B. Nayak ${ }^{1}$. Sunil B. Thakare ${ }^{2}$
}

Received: 26 February 2019 / Accepted: 5 September 2019 / Published online: 17 September 2019

(c) The Author(s) 2019

\begin{abstract}
There has been a collaborative attempt to address the seismic vulnerability of existing structures in India after an earthquake in Bhuj, Gujarat, in 2001. Seismic diagnosis and seismic retrofit for the existing tanks have become a remarkable issue to be worked since deterioration is a cosmopolitan and natural phenomenon. It is important to know the exact reason for distress and type of distress. To manage such issues, a proper method of repair and rehabilitation with detailed plans and methodology is required. This paper is aimed at evolving systematic investigation metrology for condition ranking procedure based on the analytical hierarchy process (AHP) and strengthening by various retrofitting strategies. For that case study, an existing elevated water tank is considered, which was designed according to state of the art over 40 years ago as per old Indian Standard (IS) code. The ranking assessment of the elevated service reservoir was carried out using different non-destructive tests (NDTs). DER, i.e., degree $(D)$, extent $(E)$ and relevancy $(R)$ rating technique was employed to find out the condition index of the elevated service reservoir (ESR). After finding the condition ranking of the existing structure, an analysis was carried out using SAP 2000 to find the present-day seismic requirements using IS codes. After knowing the seismic demand of the water tank, various retrofitting methods were adopted for improving the drift capacity and flexural capacity of the structure. The results were finally used to address some of the critical issues of the seismic response of the retrofitted structure in terms of a time period, mode shapes, base shear, displacement, acceleration, and velocity. From the case study result of seismic retrofit for the existing elevated water tank, it is confirmed that a relatively simple seismic retrofit method is effective to keep the tank functional after an earthquake.
\end{abstract}

Keywords Condition ranking $\cdot$ Strengthening $\cdot$ Retrofitting $\cdot$ Non-destructive $\cdot$ Seismic response $\cdot$ Elevated water tank

\section{Introduction}

A large number of existing reinforced concrete structures throughout the cosmos are in pressing need for strengthening, repair or reconstruction because of deterioration. Direct observation of these structures has shown that damage usually occurs in beams and columns. The failure is mainly due to an increase in stress levels and deteriorations of the members. Hence, retrofitting of these structures to improve their strength is significant and vital. Numerous techniques

Chittaranjan B. Nayak

cbnnayak@gmail.com

1 Department of Civil Engineering, Vidya Pratishthan's Kamalnayan Bajaj Institute of Engineering and Technology, Baramati, Pune, India

2 Anantrao Pawar College of Engineering \& Research, Pune, India have been originated and applied to improve the seismic behavior of these structures (Omidinasab and Shakib 2012; Khan et al. 2014; Nayak et al. 2018). The main objective of this research is to assess the present condition and rehabilitate the existing damaged ESR. To appraise the stability of the structure for further utilization, it is proposed to find out the structure condition index (CI) using various NDT methods. After that, analysis is done using SAP 2000 to find the present-day seismic requirements considering IS code 1893. Once the investigation of the root cause of failure is found out, then strengthening of the structure is carried out using various retrofitting methods.

For the last few decades, many researchers were involved in the analysis of the water tank through various approaches. Ortega and Robles (2016) studied the experimental monitoring of the behavior of reinforced concrete beams with different reinforcement dispositions. Zhu and François (2013) proposed the effect of chloride corrosion on the reinforcement 
bars. They have studied the influence of corrosion on the residual mechanical performance of a corroded beam at the age of 26 years. Sasmal and Ramanjaneyulu (2008) studied fuzzy logic-based methodology for condition rating of existing reinforced concrete bridges. Computer programs have been developed for condition index of existing bridges. Massimiliano and Alberto (2017) studied nonlinear time history analysis for seismic retrofitting of multiple building structures using the base isolation technique. Mishra et al. (2015) suggested and implemented RC jacketing technique using an anticorrosive agent, micro concrete, and polymer-modified mortar for retrofitting. Alireza (2015) studied the types of dampers and their performance during an earthquake. Also, they have investigated the tall buildings in the world and a satisfactory level of damper performance. Motamedi and Nateghi-A (2018) presented a unique energy-dissipating accordion metallic damper originating from corrugated thin-walled tube to improve the lateral ductility, energy dissipation, and damping potential of a frame. The behavior of the accordion metallic damper was studied analytically and experimentally. Bozorgmehrnia et al. (2013) studied an elevated water tank having a capacity of $900 \mathrm{~m}^{3}$, exposed to three pairs of earthquake records in time history using mechanical and finite-element modeling technique. Comparison between static and dynamic analysis of elevated water tank was studied by Gaikwad and Mangulkar (2013) by considering the hydrodynamic effect on the elevated water tank, to compare the effects of impulsive and convective pressure. Morfidisa and Kostinakis (2019) studied the seismic damage state using artificial neural networks (ANN)-based methods such as multilayer feedforward perceptron networks (MFPN) and the radial-basis function networks (RBFN) and led to the best configured MFPN and RBFN on the basis of the optimization of their predictions about the seismic damage state of the samples and concluded that the MFPNs were more efficient than the RBFNs. Jagadale et al. (2019) carried out a case study on a bridge model for determining the damages using PZT patches and found that there were noticeable changes in frequencies for moderate and severe damages, hence proving the efficiency of PZT. Nayak et al. (2019) studied the earthquake and wind analysis of tall structures with circular, square and rectangular plan. Finally, the various results were compared with braced tube structures and diagrid structures. Seismic upgrading of the existing walls and prediction of inelastic response of the walls with the openings were studied by Kakolvand and Motamedi (2012). Finite elements modeling of existing unreinforced concrete block walls were carried out for the study for evaluation of the proposed retrofit solutions used in practice.

Though a considerable amount of research has been done in water tank residual life assessment, health monitoring and structural reliability, researchers have not been paid much attention, for combined analysis of condition assessment and advanced method of retrofitting of water tank, considering the modified parameter of the Indian seismic code. The accuracy of the data about its condition and the complexity of structure make the problem more complicated. Further, a huge societal and financial impact for a decision on choosing immediate repair measures or replacement of most deficient water tank among many tanks, but still it follows a personal judgment. Till date, no systematic approach and methodology have been developed for prioritization or ranking, so that structural engineers or the decision makers have been facing problems. For better management and decisionmaking, a systematic procedure has been presented in this paper to facilitate advanced seismic retrofitting and condition assessment of the existing water tank. The methodology presented in this paper through a case study would help structural engineers and decision-makers to determine water tanks requiring repair, for proper utilization of public money as well as for a decreased number of catastrophic failures.

\section{Reinforcement corrosion}

Collapse does not necessarily signify structural collapse only. Corrosion in concrete reinforcement is also a major contributory factor for early deterioration, leading to structural collapse. Corrosion of reinforcing steel in concrete is a serious problem from the point of persuasion of both safety and economy. There is a clear-cut need, from both the field of research in reinforcement corrosion in concrete construction and industrial requirement. Precise calculation of structural damage can assist civil engineers in achieving a structural safety and cost-effective approach to corrosion-affected concrete structures. Concrete provides corrosion resistance to the steel chemically due to its high $\mathrm{pH}$ and physically working as a barrier. However, reinforcing steel does corrode. The two main usual causes are a general breakdown of passivity due to the neutralization of the concrete by a reaction with atmospheric carbon dioxide and localized breakdown of the passive film on the steel by chloride ions. Therefore, it is indispensable to have authentic measurement techniques to assess the corrosion condition of the steel bars in the reinforcing concrete. Corrosion represents the full extent of the damage, or they may point to problems of more significant magnitude. The corrosion mechanism is complex, involving chemical, electrochemical, and physical operations. The parameters that impact corrosion progression is concrete cover thickness, quality of concrete, environmental conditions, $\mathrm{pH}$ value, chloride level in concrete, the presence of cracks, etc. (Poursaee et al. 2010; Nayak and Thakare 2017a, b; Sohail et al. 2015). 


\section{Retrofitting and repairs}

When the structures get old and not constructed properly considering proper loads, they start showing the need for strengthening and retrofitting to enhance their strength and life. Among all the natural disasters, earthquakes, being the most destructive and affecting structures, have also created a need to raise the current safety levels in structures. As per the recommendations of the prevalent codes, several existing structures were analyzed, designed and detailed. Such structures regularly may not meet the present seismic requirements and, consequently, strengthening and retrofitting of these structures are essential (Nayak and Thakare 2016). To make existing weak structures safe against future natural forces and possible earthquakes, retrofitting is one of the best options. For retrofitting strategy, many other factors are considered for decision-making and few have been listed below.

- When the structures are analyzed and designed for gravity loads only.

- When codes of practice, standards, and seismic zone map are not revised timely.

- When structure does not fulfill current design requirement as per seismic code due to the change in loading.

- When in the case of structure and material deterioration, the resistance level of the structure decreases and it will not be able to carry the present-day load requirements.

- When constructed with a lack of understanding by the engineer, inappropriate planning and lousy quality of construction.

There are many retrofitting methods available, such as adding a new shear wall, infill wall, wing wall, buttresses, jacketing, strengthening by the steel plate bonding method, casing, and propping up bracing. Apart from these, new technologies, and materials from research work have also been developed. Based on the response control to increase the strength such as tuned mass, tuned liquid dampers, viscoelastic dampers, friction dampers, lead extrusion dampers, and base isolation FRP wrapping etc. The primary purpose of retrofitting is to increase the stiffness of structure by strengthening it by an economic retrofitting method with respect to its previous condition (Kumar 2016; Banu et al. 2012; Fayyadh et al. 2011; Vesmawala and Kodag 2017).

\section{Methodology}

The methodology of this research work is divided into two subparts, i.e., condition ranking using DER rating after various corrosion investigations and seismic analysis method for analysis of the water tank after and before retrofitting.
Table 1 Interpretation of results

\begin{tabular}{ll}
\hline Percentage chance of corrosion activity & Potential level \\
\hline $10 \%$ & Less than -200 \\
Uncertain & -200 to -350 \\
$90 \%$ & -350 to -500 \\
$95 \%$ & Above -500 \\
\hline
\end{tabular}

Table 2 Interpretation of profometer readings

\begin{tabular}{ll}
\hline Interpretation & Test result \\
\hline Relatively not & Good quality concrete and required cover thickness \\
Corrosion prone & Bad quality concrete and required cover thickness \\
Corrosion prone & $\begin{array}{c}\text { Good quality concrete and very less cover thick- } \\
\text { ness }\end{array}$ \\
\hline
\end{tabular}

\section{Corrosion investigation methods}

To evaluate the condition index of the structure, corrosion assessment of the water tank is carried out. For corrosion investigation, different NDT methods are used such as a halfcell potential, cover depth measure, and surface hardness. The details of these methods are discussed below.

\section{Half-cell potentiometer test}

Reinforcement corrosion is an electrochemical process. Half-cell potential is used to evaluate the presence of corrosion and potential vulnerability of element surface area to corrosion. The corrosion activity was found out due to the process of oxidation using the potential developed at the electrode of a half-cell. In an electrochemical cell, the overall potential is the total potential calculated from the potentials of two half cells. The higher the potential, the greater is the risk of corrosion occurrence. Interpretation of test results as per ASTM C876 has outlined the following probability levels for steel corrosion against measures of copper/copper sulfate half-cell potentials, as shown in Table 1 (ASTM C876-91 1999).

\section{Profometer}

To improve the durability of the concrete structure and to prevent corrosion, the minimum cover to reinforcement is necessary. To compute the actual strength of concrete structures, cover to reinforcement, the grade of concrete and number of reinforcing bars are required. It is becoming challenging in old structures if detailed drawings are not available. The interpretation of the result obtained from the rebar locator is given in Table 2 . 
Table 3 Comparative hardness of the cover zone

\begin{tabular}{ll}
\hline Concrete quality & $\begin{array}{l}\text { Avg. } \\
\text { rebound } \\
\text { number }\end{array}$ \\
\hline Poor & $<20$ \\
Fair & $20-30$ \\
Good & $30-40$ \\
Very hard, very good & $>40$ \\
\hline
\end{tabular}

\section{Surface hardness}

The test is conducted to assess the condition of cover concrete and to identify any delamination. Locations having very low rebound numbers will be distinguished as corrosion-prone locations. The interpolation of the result is given in Table 3 (IS 13311 1992).

\section{Condition rankings/condition index (CI)}

It is a numerical index of damage level of the element and the whole structure, based on in situ tests and visual observation of the intensity and extent of damage and judging the urgency of repair. The assessment is based on physical deterioration as determined by measurable distress. The CI is represented by a quantitative ranking between 0 and 100 , with 0 being the worst condition and 100 being the best condition (Greimnn et al. 1990; Wankhade and Landage 2013). The CI scales were used to convert the physical state of the structure into quantitative values, as shown in Table 4.

\section{Non-destructive evaluation by DER rating}

Based on the result obtained from the NDT testing, the structural adequateness is computed using the CI. The formula for
Table 5 DER rating scale for visual inspection

\begin{tabular}{llllll}
\hline Rating & 4 & 3 & 2 & 1 & 0 \\
\hline$D$ & Severe & Poor & Fair & Good & No such item \\
$E$ & $<$ High & $<60 \%$ & $<30 \%$ & $<10 \%$ & Cannot be inspected \\
$R$ & High & Medium & Small & Minor & Cannot be decided \\
\hline
\end{tabular}

Table $6 D$ value rating for corrosion test

\begin{tabular}{ll}
\hline Test results & $\begin{array}{l}D \text { value } \\
\text { rating }\end{array}$ \\
\hline$V_{\mathrm{e}}<V_{1}$ & 4 \\
$V_{1} \leq V_{\mathrm{e}}<V_{2}-0.5 \Delta V$ & 3 \\
$V_{2}-0.5 \Delta V \leq V_{2}<V_{\mathrm{e}}$ & 2 \\
$V_{2} \leq V_{\mathrm{e}}$ & 1 \\
None & 0 \\
\hline
\end{tabular}

$V_{\mathrm{e}}$ is the measured electrical potential; $V_{1}=-350 \mathrm{mV}, V_{2}=-200 \mathrm{mV}$ when electrical solution is $\mathrm{CuSO}_{4}$, while $V_{1}=-90 \mathrm{mV}$, $V_{2}=-240 \mathrm{mV}$ when electrical solution is $\mathrm{AgNO}_{3}$

$\mathrm{CI}$ is grounded in a point deduction system and weight average method. The CI of each inspection component can be found out first. Then the CI of each item is deducted from a perfect score of 100 to find out the overall deficiencies score point of the water tank. In the current approach, an evaluation method can be evolved by separating water tank deterioration into $D$ (degree of defect), $E$ (extent of defect) and $R$ (relevance of defect). The DER rating is based on a point system from 0 (no defect) to 4 (most severe). A combination field and visual inspection are employed for calculating the ' $D$ ', ' $E$ ', and ' $R$ ' values. The values of $E$ and $R$ are calculated from visual inspection as per Table 5. The value of $D_{\max }$ is calculated from the maximum value of $D$ from corrosion test, rebar locater test, and rebound hammer test from Tables 6, 7 and 8, respectively.

Table 4 Condition index scale

\begin{tabular}{|c|c|c|c|c|}
\hline Zone & CI value & Condition & Description & Action \\
\hline \multirow[t]{3}{*}{03} & $0-9$ & Failed & $\begin{array}{l}\text { General failure or failure of a major component } \\
\text { No longer functional }\end{array}$ & \multirow{3}{*}{$\begin{array}{l}\text { Detailed evaluation is required to determine the need for } \\
\text { repair, rehabilitation or reconstruction. Safety evalua- } \\
\text { tion is recommended }\end{array}$} \\
\hline & $10-24$ & Very poor & $\begin{array}{l}\text { Extensive deterioration } \\
\text { Barely functional }\end{array}$ & \\
\hline & $25-39$ & Poor & $\begin{array}{l}\text { Serious deterioration in at least some portions of } \\
\text { structure } \\
\text { Function seriously impaired }\end{array}$ & \\
\hline \multirow[t]{2}{*}{02} & $40-54$ & Fair & $\begin{array}{l}\text { Moderate deterioration } \\
\text { Function not seriously impaired }\end{array}$ & \multirow[t]{2}{*}{$\begin{array}{l}\text { Economic analysis of repair alternatives is recommendec } \\
\text { to determine appropriate action }\end{array}$} \\
\hline & $55-69$ & Good & $\begin{array}{l}\text { Some deterioration or defects evident } \\
\text { Function not impaired }\end{array}$ & \\
\hline \multirow[t]{2}{*}{01} & $70-84$ & Very good & Only minor deterioration or defects evident & \multirow[t]{2}{*}{ Immediate action is not required } \\
\hline & $85-100$ & Excellent & $\begin{array}{l}\text { No noticeable defects } \\
\text { Some aging or wear may be visible }\end{array}$ & \\
\hline
\end{tabular}


Table $7 \quad D$ value rating for cover depth meter test

Table $8 D$ value rating for rebound hammer test

\begin{tabular}{ll}
\hline Test results & $\begin{array}{l}D \text { value } \\
\text { rating }\end{array}$ \\
\hline$D_{\mathrm{t}}<0.25 D_{\mathrm{e}}$ & 4 \\
$0.25 D_{\mathrm{e}} \leq D_{\mathrm{t}}<0.5 D_{\mathrm{e}}$ & 3 \\
$0.5 D_{\mathrm{e}} \leq D_{\mathrm{t}}<0.75 D_{\mathrm{e}}$ & 2 \\
$0.75 D_{\mathrm{e}} \leq D_{\mathrm{t}}$ & 1 \\
$D_{\mathrm{e}} \leq D_{\mathrm{t}}$ & 0 \\
\hline
\end{tabular}

$D_{\mathrm{e}}$ and $D_{\mathrm{t}}$ are the design concrete cover thickness and in situ concrete cover thickness

\begin{tabular}{ll}
\hline Test results & $\begin{array}{l}D \text { value } \\
\text { rating }\end{array}$ \\
\hline$p_{\mathrm{t}}<0.75 p_{\mathrm{d}}$ & 4 \\
$0.75 P_{\mathrm{d}} \leq p_{\mathrm{t}}<0.85 p_{\mathrm{d}}$ & 3 \\
$0.85 P_{\mathrm{d}} \leq p_{\mathrm{t}}<p_{\mathrm{d}}$ & 2 \\
$P_{\mathrm{d}} \leq p_{\mathrm{t}}$ & 1 \\
None & 0 \\
\hline
\end{tabular}

$P_{\mathrm{d}}$ and $P_{\mathrm{t}}$ are the design and test results of the concrete compression strength

Each of these parameters is combined with the prioritization module to define a priority ranking of water tanks demanding repair. Based on inspection results of all items, the CI of the water tank is worked out using Eq. (1) (Wankhade and Landage 2013):

$\mathrm{CI}=\frac{\sum_{i=1}^{n} I_{\mathrm{c}_{i}} \times w_{i}}{\sum_{i=1}^{n} w_{i}}, \quad$ where $\sum_{i=1}^{n} w_{i}=100$,

where, $W_{i}$, is the weighting of the water tank components. (Assume that the total weight of an all component group value is 10,100,1000-so on, it is not unique), in which ' $n$ ' is the number of relevant inspection items and $I_{\mathrm{c}_{i}}$ is the condition index of each component calculated as in Eq. (2) (Wankhade and Landage 2013):

$I_{\mathrm{c}_{i}}=100-100 \times \frac{[\max (D)+E] \times R^{a}}{(4+4) \times 4^{a}}$.

The value of ' $a$ ' can be determined by the importance of the water tanks (generally the value of ' $a$ ' ranges from 1 to 2 ).

\section{Seismic analysis methods}

ESR is considered a vital lifeline structure in the many areas in India. During and after strong earthquakes, serviceability functioning is a crucial concern. During an earthquake episode, the collapse of these structures may cause several hazards to the health of citizens. ESR did not show good seismic performance; hence, remarkable damages have been observed during past earthquakes. For calculating seismic design force for a particular region or country, seismic codes are unique. In India IS (India standard) 1893-2016 is the main code for seismic analysis. The codes recommend the three methods of analysis name as equivalent static analysis, dynamic analysis: (a) response spectrum analysis, (b) time history analysis, pushover analysis respectively (IS 1893: 2002, 2016).

\section{Model provisions}

After the Chilean earthquake of 1960, two mass-spring models were proposed to distinguish the basic dynamic properties of the elevated tank. The dynamic motion of the tank can be divided into two parts, viz convective and impulsive when the pressure is generated within the fluid. Horizontal acceleration developed on the tank wall and liquid when the tank was subjected to horizontal earthquake ground motion when containing a liquid with a free surface (Housner 1963).

Lower region liquid mass, i.e., impulsive mass $\left(m_{\mathrm{i}}\right)$, is rigidly attached to the tank wall. The upper region liquid, i.e., convective mass $\left(m_{\mathrm{c}}\right)$, is attached to the tank wall by the spring having stiffness $\left(K_{\mathrm{c}}\right)$ in the spring-mass model. Instead of the spring-mass model, elevated tanks are considered as two-mass model systems with two degrees of freedom because two-mass model idealization is nearer to actuality. Figure 1 shows a two-mass model of an elevated water tank. The response can be obtained using elementary structural dynamics for two degrees of freedom systems. However, it is observed that both the time periods are well separated in most of the cases. Hence, two uncoupled single degrees of freedom system can be used for two mass idealizations. The stiffness $\left(k_{\mathrm{s}}\right)$ and mass $\left(m_{\mathrm{s}}\right)$ is lateral stiffness of the staging and structural mass of an elevated tank respectively. Structural mass $\left(m_{\mathrm{s}}\right)$ includes one-third mass of staging and the container mass acts as a lateral spring.

\section{Time history analysis}

The overall seismic performance evaluation of a structure must be based on its as-built information, type of structure, location of the structure, orientation, material strength, etc. Generally, four different procedures, such as the linear static, the linear dynamic, the nonlinear static and the nonlinear dynamic procedures, are available for the seismic evaluation of existing structures. The results of linear static analyses are used to design the structures. The linear dynamic analysis provides the idea regarding the natural period and mode shapes of the structures. 
Fig. 1 Spring mass model and two mass idealizations for elevated tank

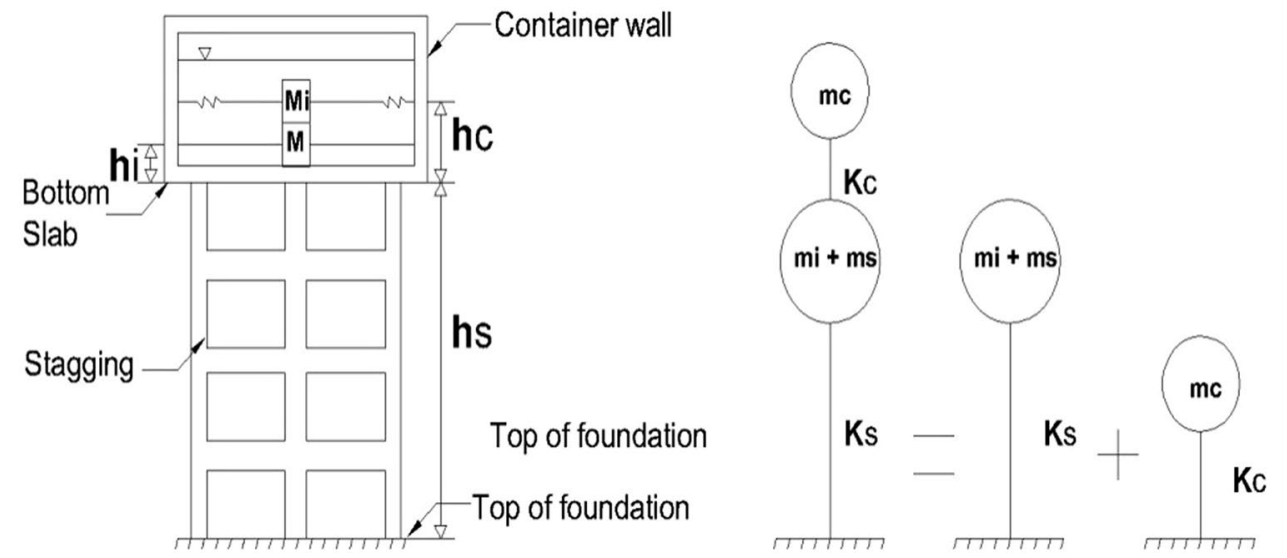

Nonlinear static, i.e., pushover analysis, gives the estimation of the capacity of the structure. The capacity of the structure is dependent solely on the capacity of its members. Hence, truly speaking, the distribution of the loading on the structure should not affect the results of pushover analysis. The effect of mass distribution along the height of the structure will affect the dynamic response of the structure. In this respect, nonlinear time history analysis is capable of showing the differences in the behavior of the frames. This research work presents the comparison of dynamic seismic response of the water tank and staging frames by linear time history analyses, for a set of selected ground motion records.

\section{Uttarkashi earthquake}

The first of the major earthquakes to strike the Indian subcontinent in the 1990s, the quake-devastated Garhwal, especially Uttarkashi, Tehri, and Chamoli districts on Dusshera night occurred at 02:53:16 October 20,1991, local time with a moment magnitude of 6.1 and a maximum Mercalli intensity of IX (Violent). The northeast of the Uttarkashi region of the Higher Himalaya is the epicenter of the destructive earthquake. Table 9 summarizes the earthquake data. The magnitude of the earthquake was assigned as 6.1 by the Indian Meteorological Department (IMD) based on body wave data. The United States Geological Survey (USGS) assigned a surface wave magnitude of 7.1. There was confusion about the epicenter of the earthquake, with preliminary estimates by IMD indicating its location close to Almora, about $170 \mathrm{~km}$ from Uttarkashi (Nayak and Thakare 2017a, b).

Table 9 Selected ground motions

\section{Retrofit measures for ESR}

The primary purpose of retrofitting is to increase the stiffness and reduce the seismic demand of the structure with respect to its previous condition. In this research work, retrofitting techniques used are diagonal braces as a retrofitting system, FRP as a newly emerging material, and damper as technology.

In this seismic retrofit method, diagonal braces are installed on ESR to be retrofitted to absorb earthquake energy input to the ERS and thereby enhance its seismic performance. Figure 2a shows the SAP 2000 model with the addition of the diagonal braces. The material properties of bracing are the size of bracing $0.2 \mathrm{~m} \times 0.6 \mathrm{~m}$ and stiffness of bracing $100 \mathrm{kN} / \mathrm{mm}$, with $5 \%$ damping as tension and compression member. Figure $2 b$ shows that the configuration of a damper improves the seismic resistance performance of the existing ESR by giving damping. The damper properties are stiffness $200 \mathrm{kN} / \mathrm{mm}$, 5\% of critical damping (damper properties are worked out for targeted displacement or permissible displacement or to control the displacement), damping coefficient 200 and damping exponent 1. Wrapping around the surfaces of concrete structures increases the durability and the ductility of the structural members. Figure $2 \mathrm{c}$ shows the SAP 2000 model retrofitted with FRP. The material properties of FRP are specific gravity $1.75 \mathrm{~g} / \mathrm{cm}^{3}$, tensile strength $3100 \mathrm{~N} / \mathrm{mm}^{2}$, and modulus of elasticity $220,000 \mathrm{~N} / \mathrm{mm}^{2}$.

\section{Results and discussions}

A guideline for identifying the primary causes of deterioration in the district of Pune and a guideline for the selection of suitable condition assessment of reinforced concrete

\begin{tabular}{lllllll}
\hline S. no. & Name of ground motion & PGA & Richter magnitude & Year & Duration (s) & Scaling factor \\
\hline 1. & Uttarkashi & $0.30 \mathrm{~g}$ & 7.1 & 1991 & 23 & - \\
\hline
\end{tabular}




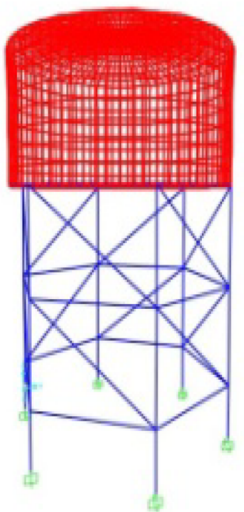

(a) Modeling with bracings

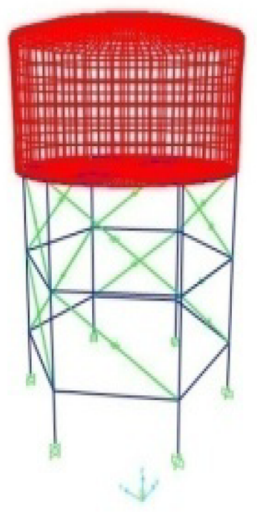

(b) Modeling with damper

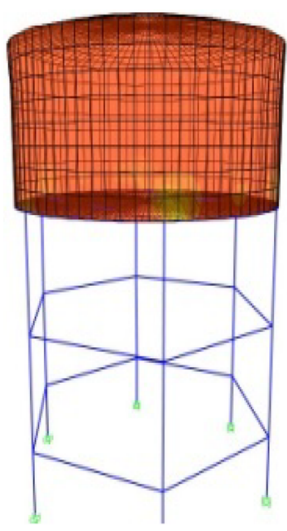

(c) Modeling with FRP

Fig. 2 Modeling of water tank with different retrofitting techniques

Table 10 Salient features of ESR

\begin{tabular}{lll}
\hline S. no & Features & Description \\
\hline 01 & Period of construction & \\
02 & Location & Baramati, Pune \\
03 & Owned and maintained & Baramati Nagar Palika \\
04 & Total period of use & 40 years \\
05 & Utility of water tank & Yes \\
06 & Number of columns & 06 \\
\hline
\end{tabular}

ESRs by using various NDT and strengthening by different retrofitting methods were proposed.

\section{Case study of ESR}

The following are the details of the water tank located in Baramati. The salient features are given in Table 10 and the overall view in Fig. 3.

\section{Corrosion investigation results}

To evaluate the corrosion status in the RCC ESR, a study on the assessment of corrosion-affected structure of concrete water tanks was carried out.

\section{Visual observation}

The degree of corrosion can be inspected visually by the human eye without any accompanying aids. Figure 4 shows some damages in the water tank and some observations are listed below after visual inspection. Blackish patches were seen on the dome periphery, corrosion damage of ring beam on the inner side of the ESR, and bottom the reinforcement of bracings exposed and corroded.

A detailed visual inspection was carried out on almost all assessable location, including several visually damaged members. Cracks developed on column and braces of water tank were up to $15 \mathrm{~cm}$ in length and $2-3 \mathrm{~mm}$ in width. Cracks were observed in the top dome, and the talk wall was of $1.0 \mathrm{~cm}$ length and $1 \mathrm{~mm}$ width. The maximum portion of rebars of the tank has been exposed and also corroded.

\section{Half-cell potentiometer test}

Half-cell potential testing was carried out at representative locations on braces, column, and container of ESR. For this test, exposed reinforcement bars were either located or sometimes chiseled out to provide connectivity to the instrument. The surface was cleared of any dust and deposition. Tests were conducted in a grid of $150 \times 150 \mathrm{~mm}$ using the procedure mentioned in ASTM 876. From Figs. 5 and 6, the average potential difference is in the range of $-240 \mathrm{mV}$ and $-250 \mathrm{mV}$ for column $\mathrm{C} 5$ and beam B2, respectively.

\section{Profometer}

Testing was carried out at representative locations on brace, column, and container of ESR. Results obtained in the test are as follows. Figures 7 and 8 show the details of reinforcement of column C5 and beam B2, respectively.

Tables 11 and 12 show the various parameters, statistic and measured cover for column C5 and beam B2, respectively. The concrete cover along the $X$-direction was $37.6 \mathrm{~mm}$ and along $Y$-direction $37.5 \mathrm{~mm}$ for column C5. A number of bars were measured in column $\mathrm{C} 5$, five in the 
Fig. 3 Examined structure

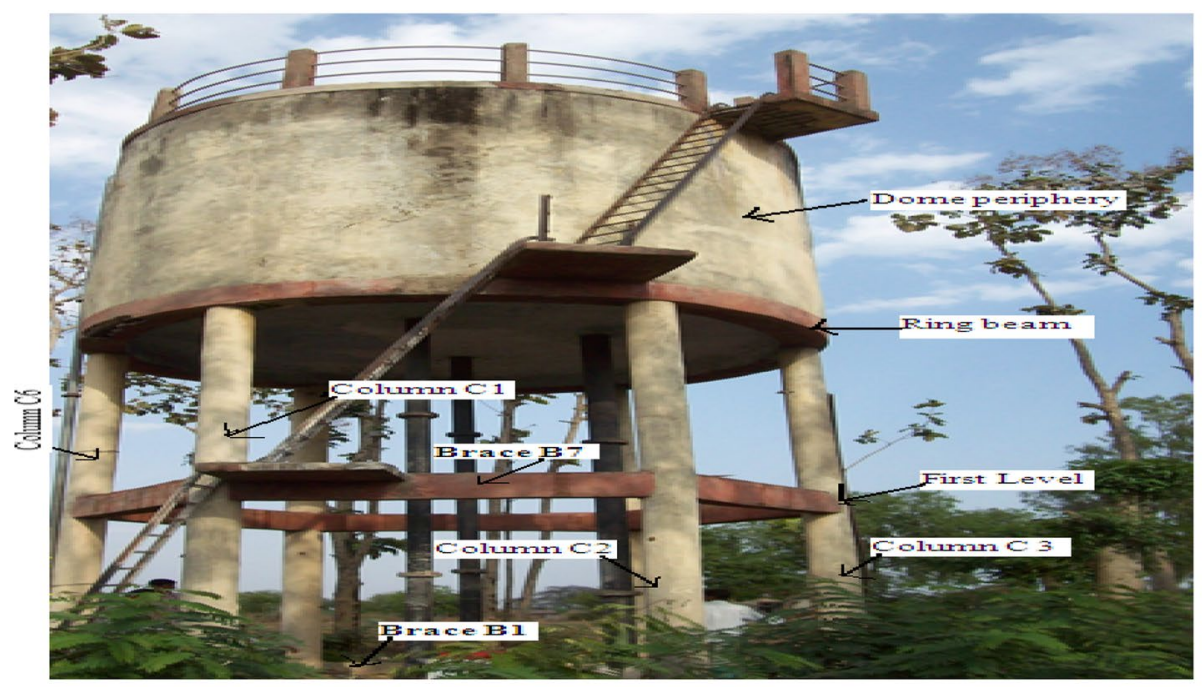

(a) Real image
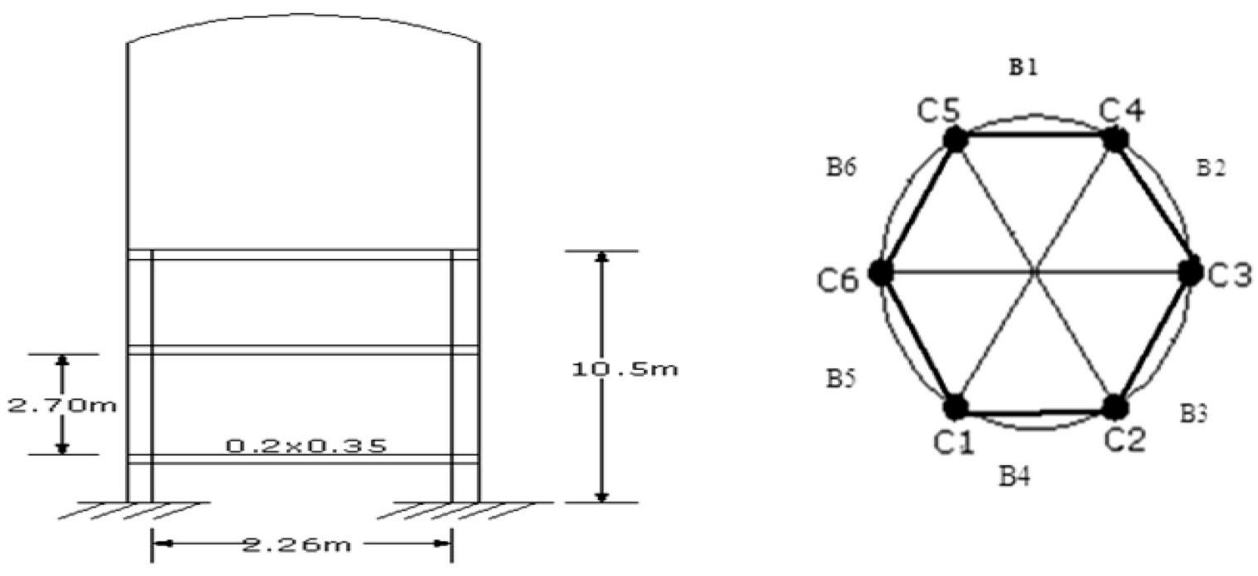

(b) Plan and elevation

Fig. 4 Corrosion damage on ring beam inner side
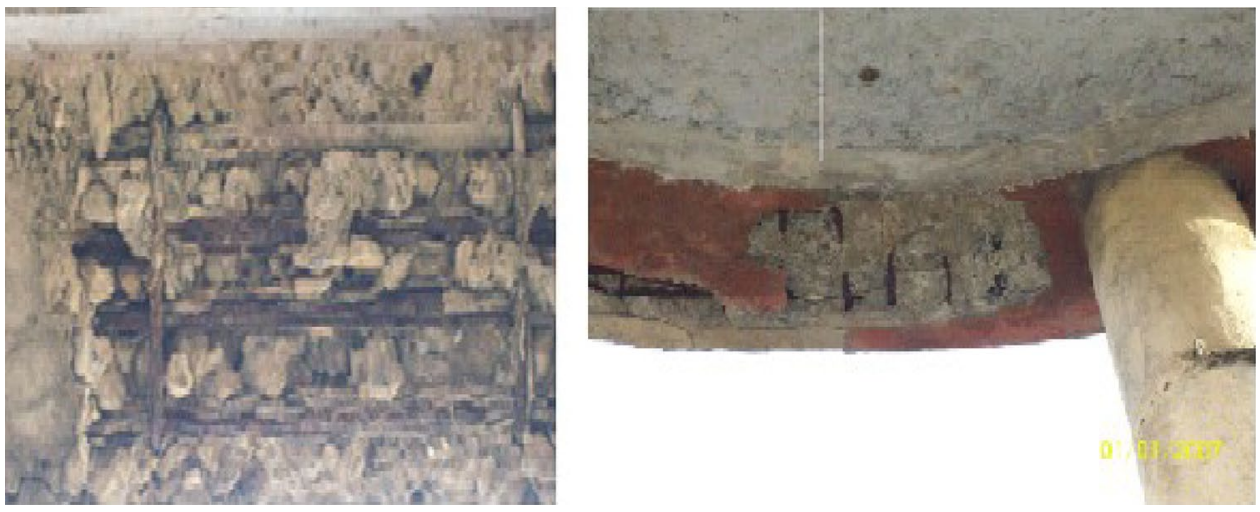
Fig. 5 Corrosion mapping of column C5

Fig. 6 Corrosion mapping of beam B2

Fig. 7 Details of reinforcement in column $\mathrm{C} 5$
Location: Column C5 of ESR

\begin{tabular}{|c|c|c|c|c|c|c|c|c|c|c|c|c|c|c|}
\hline & \multicolumn{6}{|c|}{ CA NIN } & & & & & & & & \\
\hline & \multicolumn{4}{|c|}{ Object 21} & \multicolumn{3}{|c|}{$\mathrm{COL}-\mathrm{C} 5$} & & & & & & & \\
\hline & & & & & & & & & & & & & & \\
\hline & 96. & & & 96. & & & $96.2 \mathrm{~s}$ & $92.3 \mathrm{~s}$ & $76.9 \mathrm{~s}$ & $26.9 \mathrm{~s}$ & $0.0 \mathrm{~s}$ & $0.0 \mathrm{~s}$ & $0.0 \mathrm{~s}$ & $(\%)$ \\
\hline & 0.0 & & & 0.0 & & & $4.0 \mathrm{r}$ & $16.0 \mathrm{r}$ & $52.0 \mathrm{r}$ & $28.0 \mathrm{r}$ & $0.0 \mathrm{r}$ & $0.0 \mathrm{r}$ & $0.0 \mathrm{r}$ & $(\%)$ \\
\hline & & & & & & & & & & & & & & \\
\hline & $>-1$ & 00 & & $>-1$ & & & $>-170$ & $>-205$ & $>-240$ & $>-275$ & $>-310$ & $>-350$ & $<=-350$ & $(\mathrm{mV})$ \\
\hline $\mathrm{m}$ & \begin{tabular}{l|} 
\\
\\
0
\end{tabular} & $\begin{array}{l}0 \\
\stackrel{0}{0} \\
0\end{array}$ & ণ্ণি & ? & $\begin{array}{l} \\
\\
0 \\
\end{array}$ & $\begin{array}{l}0 \\
n \\
\vdots \\
0\end{array}$ & \begin{tabular}{l|l}
0 & 0 \\
0 & \\
0 &
\end{tabular} & & & & & & & \\
\hline 0.0 & & & & & & & & & & & & & & \\
\hline 0.1 & & & & & & & & & & & & & & \\
\hline 0.2 & & & & & & & & & & & & & & \\
\hline 0.3 & & & & & & & & & & & & & & \\
\hline 0.4 & & & & & & $\mathrm{x}$ & $\mathrm{X}$ & & & & & & & \\
\hline
\end{tabular}

\section{Location: Bottom brace B2 of ESR}

\begin{tabular}{|c|c|c|c|c|c|c|c|c|c|c|c|c|c|c|c|}
\hline & \multicolumn{5}{|c|}{ CANIN } & & & & & & & & & & \\
\hline & \multicolumn{4}{|c|}{ Object 18} & \multicolumn{4}{|c|}{ Beam- B2 } & & & & & & & \\
\hline & & & & & & & & & & & & & & & \\
\hline & \multicolumn{2}{|c|}{$94.1 \mathrm{~s}$} & & \multicolumn{2}{|c|}{$94.1 \mathrm{~s}$} & & \multicolumn{2}{|c|}{$94.1 \mathrm{~s}$} & $94.1 \mathrm{~s}$ & $94.1 \mathrm{~s}$ & $94.1 \mathrm{~s}$ & $82.2 \mathrm{~s}$ & $82.4 \mathrm{~s}$ & $76.5 \mathrm{~s}$ & $(\%)$ \\
\hline & \multicolumn{2}{|c|}{$0.0 \mathrm{r}$} & & \multicolumn{2}{|c|}{$0.0 \mathrm{r}$} & & \multicolumn{2}{|c|}{$0.0 \mathrm{r}$} & $0.0 \mathrm{r}$ & $0.0 \mathrm{r}$ & $6.3 r$ & $6.3 \mathrm{r}$ & $8.3 \mathrm{r}$ & $83.3 \mathrm{r}$ & $(\%)$ \\
\hline & & & & & & & & & & & & & & & \\
\hline & \multicolumn{2}{|c|}{$>-100$} & & \multicolumn{2}{|c|}{$>-135$} & & \multicolumn{2}{|c|}{$>-170$} & $>-205$ & $>-240$ & $>-275$ & $>-310$ & $>-350$ & $<=-350$ & $(\mathrm{mV})$ \\
\hline & & & & & & & & & & & & & & & \\
\hline $\mathrm{m}$ & $\begin{array}{l}8 \\
0\end{array}$ & $\frac{0}{0}$ & ¿े & 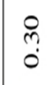 & $\begin{array}{l}\stackrel{q}{+} \\
\stackrel{0}{0}\end{array}$ & $\begin{array}{l}0 \\
\stackrel{n}{0} \\
0\end{array}$ & $\begin{array}{l}\circ \\
: \\
0\end{array}$ & $\begin{array}{l}\stackrel{0}{0} \\
\vdots\end{array}$ & & & & & & & \\
\hline 0.0 & & & & & & & & & & & & & & & \\
\hline 0.1 & & & & & & & & & & & & & & & \\
\hline 0.2 & $x$ & $x$ & & & & & & & & & & & & & \\
\hline
\end{tabular}

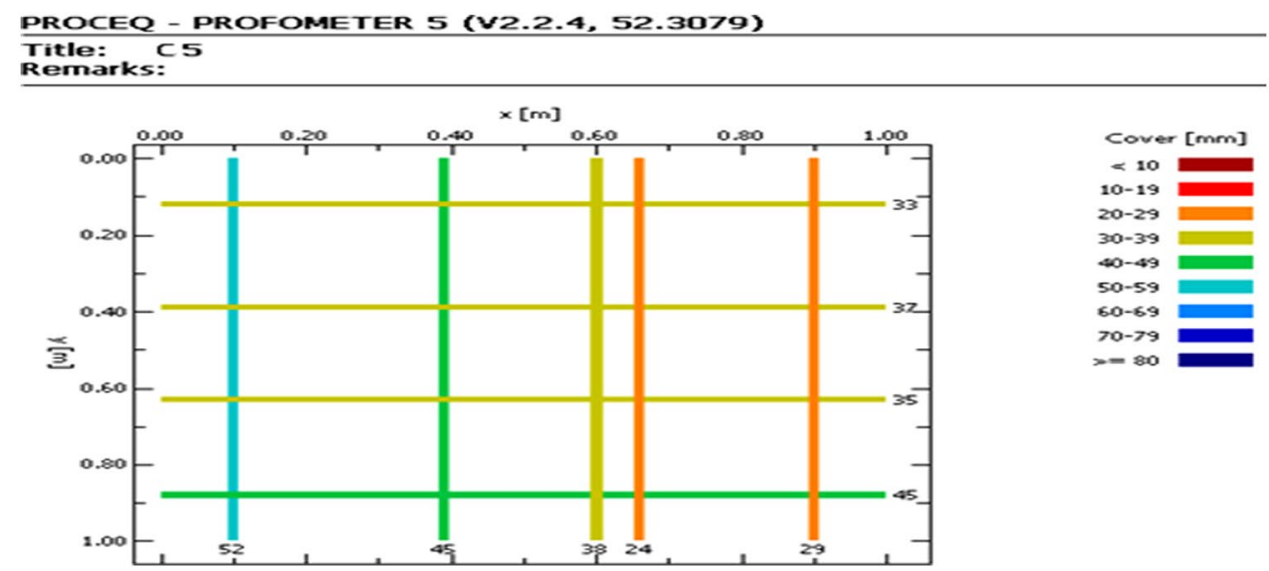

$X$-direction and four in the $Y$-direction. The profometer rebar locator test on beam B2 gives an average concrete cover along $X$-direction $55.5 \mathrm{~mm}$ and along $Y$-direction $47.0 \mathrm{~mm}$. The number of bars measured in beam B2 of ESRs was two in the $X$-direction and two in the $Y$-direction.

\section{Surface hardness}

To calculate the compressive strength of the water tank at the site, rebound hammer test was performed. The test points 
Fig. 8 Details of reinforcement in beam B2
PROCEQ - PROFOMETER 5 (V2.2.4, 52.3079$)$

$$
\begin{aligned}
& \text { Title: BEAM NOZ } \\
& \text { Remarks: }
\end{aligned}
$$

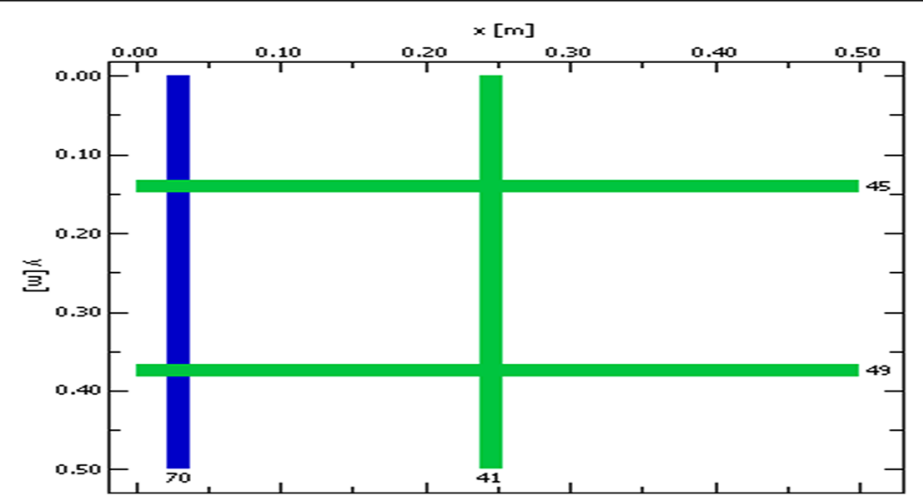

over $[\mathrm{mm}]$

$<10$

$10-19$

$20-29$

$30-39$

$50-59$

$60-69$

$70-79$

$=80$
Table 11 Parameters and results of profometer for column $\mathrm{C} 5$

\begin{tabular}{|c|c|c|c|}
\hline \multicolumn{4}{|l|}{ Set parameters } \\
\hline \multicolumn{2}{|l|}{ Bar diameter $(D)$} & \multicolumn{2}{|l|}{$16 \mathrm{~mm}$} \\
\hline \multicolumn{2}{|l|}{$X$ grid width $(\mathrm{d} X)$} & \multicolumn{2}{|l|}{$10 \mathrm{~mm}$} \\
\hline \multicolumn{2}{|l|}{$Y$ grid width $(\mathrm{d} Y)$} & \multicolumn{2}{|l|}{$10 \mathrm{~mm}$} \\
\hline \multicolumn{4}{|l|}{ Statistics } \\
\hline \multicolumn{2}{|l|}{ Direction } & $X$ & $Y$ \\
\hline \multicolumn{2}{|l|}{ Number of measured bars } & 05 & 04 \\
\hline \multicolumn{2}{|l|}{ Average measured cover } & $37.6 \mathrm{~mm}$ & $37.5 \mathrm{~mm}$ \\
\hline \multicolumn{2}{|l|}{ Standard deviation } & $11.4 \mathrm{~mm}$ & $5.3 \mathrm{~mm}$ \\
\hline \multicolumn{2}{|l|}{ Maximum of measured covers } & $52 \mathrm{~mm}$ & $45 \mathrm{~mm}$ \\
\hline \multicolumn{2}{|l|}{ Minimum of measured covers } & $24 \mathrm{~mm}$ & $33 \mathrm{~mm}$ \\
\hline \multicolumn{2}{|l|}{ Span } & $28 \mathrm{~mm}$ & $12 \mathrm{~mm}$ \\
\hline \multicolumn{4}{|l|}{ Measured covers } \\
\hline$X(\mathrm{~m})$ & Cover $(\mathrm{mm})$ & $Y(\mathrm{~m})$ & Cover (mm) \\
\hline 0.10 & 52 & 0.12 & 33 \\
\hline 0.39 & 45 & 0.39 & 37 \\
\hline 0.60 & 38 & 0.63 & 35 \\
\hline 0.66 & 24 & 0.88 & 45 \\
\hline 0.90 & 29 & & \\
\hline
\end{tabular}

included specific points on the columns, beam's top dome and container, and the results are interpreted as per Table 13.

\section{Analysis of condition index}

Condition index is determined by NDT evaluation by DER Rating approach of all the component/element of the water tank.

- Design strength of concrete $p_{\mathrm{d}}=25 \mathrm{~N} / \mathrm{mm}^{2}$.

- Design concrete cover for columns $D_{\mathrm{c}}=50 \mathrm{~mm}$.

- Design concrete cover for brace beams $D_{\mathrm{c}}=50 \mathrm{~mm}$.

- Design concrete cover for tank container, top dome, and staircase $D_{\mathrm{c}}=25 \mathrm{~mm}$.
- Parameter ' $a$ ' is related to the importance of water $\operatorname{tank}=2$.

- Number of components of water tank $n=15$.

Condition ranking/condition index for column C5 $\left(I_{\mathrm{c}_{1}}\right)$.

- Value of ' $E$ ' and ' $R$ ' from visual inspection using Table 5 is $E=3$ and $R=4$.

- Average potential difference measured by half-cell potential $V_{\mathrm{e}}=-240 \mathrm{mV}$, from Table $6, D=1$.

- Average cover measured by rebar locator $D_{\mathrm{t}}=37.6 \mathrm{~mm}$, then from Table $7, D=1$. 
Table 12 Parameters and results of profometer for beam B2

\begin{tabular}{|c|c|c|c|}
\hline \multicolumn{4}{|l|}{ Set parameters } \\
\hline \multicolumn{2}{|l|}{ Bar diameter $(D)$} & \multicolumn{2}{|l|}{$16 \mathrm{~mm}$} \\
\hline \multicolumn{2}{|l|}{$X$ grid width $(\mathrm{d} X)$} & \multicolumn{2}{|l|}{$05 \mathrm{~mm}$} \\
\hline \multicolumn{2}{|l|}{$Y$ grid width $(\mathrm{d} Y)$} & \multicolumn{2}{|l|}{$05 \mathrm{~mm}$} \\
\hline \multicolumn{4}{|l|}{ Statistics } \\
\hline \multicolumn{2}{|l|}{ Direction } & $X$ & $Y$ \\
\hline \multicolumn{2}{|l|}{ Number of measured bars } & 2 & 2 \\
\hline \multicolumn{2}{|l|}{ Average measured cover } & $55.5 \mathrm{~mm}$ & $47 \mathrm{~mm}$ \\
\hline \multicolumn{2}{|l|}{ Standard deviation } & $20.5 \mathrm{~mm}$ & $2.8 \mathrm{~mm}$ \\
\hline \multicolumn{2}{|l|}{ Maximum of measured covers } & $70 \mathrm{~mm}$ & $49 \mathrm{~mm}$ \\
\hline \multicolumn{2}{|l|}{ Minimum of measured covers } & $41 \mathrm{~mm}$ & $45 \mathrm{~mm}$ \\
\hline \multicolumn{2}{|l|}{ Span } & $29 \mathrm{~mm}$ & $4 \mathrm{~mm}$ \\
\hline \multicolumn{4}{|l|}{ Measured covers } \\
\hline$X(\mathrm{~m})$ & Cover $(\mathrm{mm})$ & $Y(\mathrm{~m})$ & Cover $(\mathrm{mm})$ \\
\hline 0.03 & 70 & 0.14 & 45 \\
\hline 0.25 & 41 & 0.38 & 49 \\
\hline
\end{tabular}

Table 13 Results of rebound hammer

\begin{tabular}{lllllll}
\hline S. no. & Location & Rebound hammer value & Average & $\begin{array}{l}\text { Surface } \\
\text { condi- } \\
\text { tion }\end{array}$ \\
\hline 01 & C5 & 17.2 & 16.8 & 17 & 17 & Dry \\
02 & B2 & 10 & 11.1 & 11.3 & 10.8 & Dry \\
03 & Top dome & 17 & 18 & 17.5 & 17.5 & Dry \\
04 & Water tank container & 18 & 18.5 & 17.7 & 18.06 & Dry \\
\hline
\end{tabular}

The average rebound hammer value of the column $\mathrm{C} 5$ and beam B2 are $17 \mathrm{~N} / \mathrm{mm}^{2}$ and $10.8 \mathrm{~N} / \mathrm{mm}^{2}$, respectively
- Rebound hammer value measured by rebound hammer test $p_{\mathrm{t}}=17 \mathrm{~N} / \mathrm{mm}^{2}$ from Table $8, D=4$.

From the above three value of ' $D$ ' then $D_{\max }=4$, using Eq. (2):

$I_{\mathrm{c}_{1}}=100-100 \times \frac{[(4)+3] \times 4^{2}}{(4+4) \times 4^{2}}=12.5$.

Condition index for bracing beam B2 $\left(I_{\mathrm{c}_{5}}\right)$
- Average cover measured by rebar locator $D_{\mathrm{t}}=55 \mathrm{~mm}$ from Table 7, $D=2$.

- Rebound hammer value measured by rebound hammer test pt $10.8 \mathrm{~N} / \mathrm{mm}^{2}$, from Table $8, D=4$

From the above three values of ' $D$ ', $D_{\max }=4$ using Eq. (2): $I_{\mathrm{c}_{5}}=0$.

Similarly, all other components of the water tank are calculated. Finally, using Eq. (1) the CI of water tank is

$$
\begin{aligned}
\mathrm{CI} & =\frac{\sum_{i=1}^{n} I_{\mathrm{c}_{i}} \times w_{i}}{\sum_{i=1}^{n} w_{i}}, \quad \text { where } \sum_{i=1}^{n} w_{i}=100, \\
& =\frac{100+406.24+406.24+100+0+0+0+75+100+0+0+75+0+355.46+253.9}{8+8+8+8+8+8+6+6+6+6+6+6+6+5+5} .
\end{aligned}
$$

$\mathrm{CI}=18.71$.

Value of ' $E$ ' and ' $R$ ' from Table $5, E=4$ and $R=4$.

- Average potential difference measured by half-cell potential $V_{\mathrm{e}}=-250 \mathrm{mV}$ from Table $6, D=1$.
From Table 4 , the condition index scales $\mathrm{CI}=18.71$ between $\mathrm{CI}=10-24$, which implies that the condition of the water tank is very poor, extensive deterioration has occurred, and the water tank is barely functional. 
As per condition index recommendation, rehabilitation or reconstruction is required to meet up the present-day requirement.

\section{Seismic analysis and retrofitting results}

Most of the water tanks were designed based on IS "Criteria for Earthquake Resistant Design of Structures 1893", but after the occurrence of an earthquake in Gujarat (Bhuj, 26 Jan 2001) the IS code was revised by IS 1893-2002, and again revised by a new 1893-2016. Even if the codes were provided with the same type of structure, their seismic response could be quite different, which may result in a different level of residual ductility. For the safety of the existing water tank in India, the seismic analysis should be checked as per revised code IS 1893-2016 for the presentday requirement.

\section{Drift ratio of ESR}

From Fig. 9 of drift ratio of ESR, considering five different cases, it can be said that the drift ratio of the water tank is maximum as per IS code as compared to other retrofitting cases. The lowest drift was observed for the bracing system.

The value of story drift is reduced $9.50 \%, 30.01 \%$, $39.06 \%$, and $44.45 \%$ by the provision of IS $1893-2016$, for FRP, damper and bracing, respectively, as compared to IS 1893-2002.

Based on the results obtained from NDT the CI scales $=18.71$, the condition of the water tank is inferior, with extensive deterioration, and hardly functional. On the other hand, in seismic analysis, the value of story drift exceeds the limit given by IS (IS 456 2000). To maintain the given structure and to resist seismic force, retrofitting of the given structure is necessary. The water tank was retrofitted with different retrofitting techniques discussed above to maintain functionality.

\section{Base shear of ESR}

A graph is plotted taking analysis type as abscissa and base shear as ordinate for the different types of analyses.

From Fig. 10, it can be said that the value of the base shear was increased by $11.66 \%, 25.67 \%, 60.86 \%$, and $78.88 \%$ by the provision of IS $1893-2016$, for FRP, damper and bracing, respectively, as compared to IS 1893-2002.
Fig. 9 Comparison drift ratio of ESR

Fig. 10 Comparison of base shear
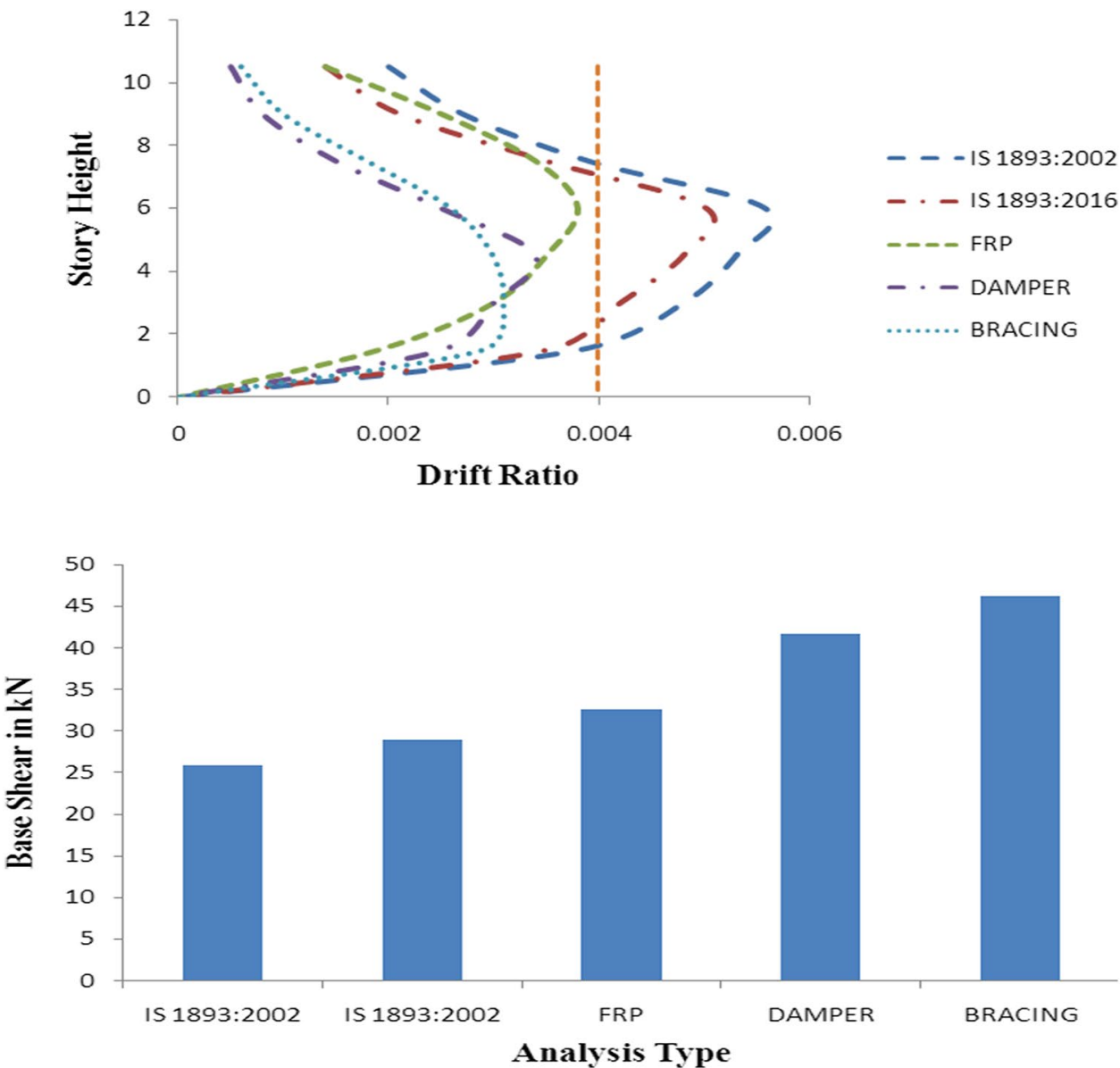
Fig. 11 Comparison between time period vs mode number

\section{Time period of ESR}

Any assumed deflection profile can be built up by a combination of modal shapes. It has been observed that the shape of higher mode for all cases is quite similar. However, the shape of the lower mode tends to differ more. It is observed in Fig. 11 that the time period for each successive mode decreases as the mode number increases.

The time period decreased $31.57 \%$ for IS $1893-2016$, $63.05 \%$ for FRP, $66.59 \%$ for damper, and $68.11 \%$ for bracing with respect to IS 1893-2002.

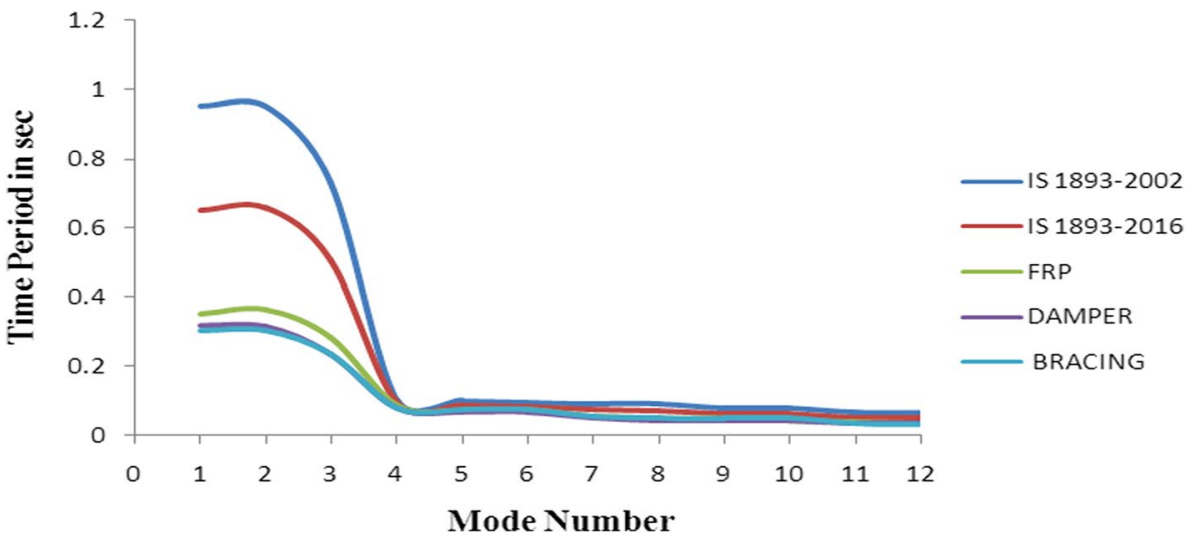

Displacement of ESR

Comparison of displacement was carried out to check the performance of the structure from consideration of serviceability.

From Fig. 12, it can be said that the displacement of the water tank was reduced $21.33 \%, 84.89 \%, 88.28 \%$, and $92.89 .45 \%$ by the provision of IS $1893-2016$, for FRP, damper and bracing, respectively, as compared to IS 1893-2002.
Fig. 12 Comparison between displacement vs time period

Fig. 13 Comparison between velocity vs time period

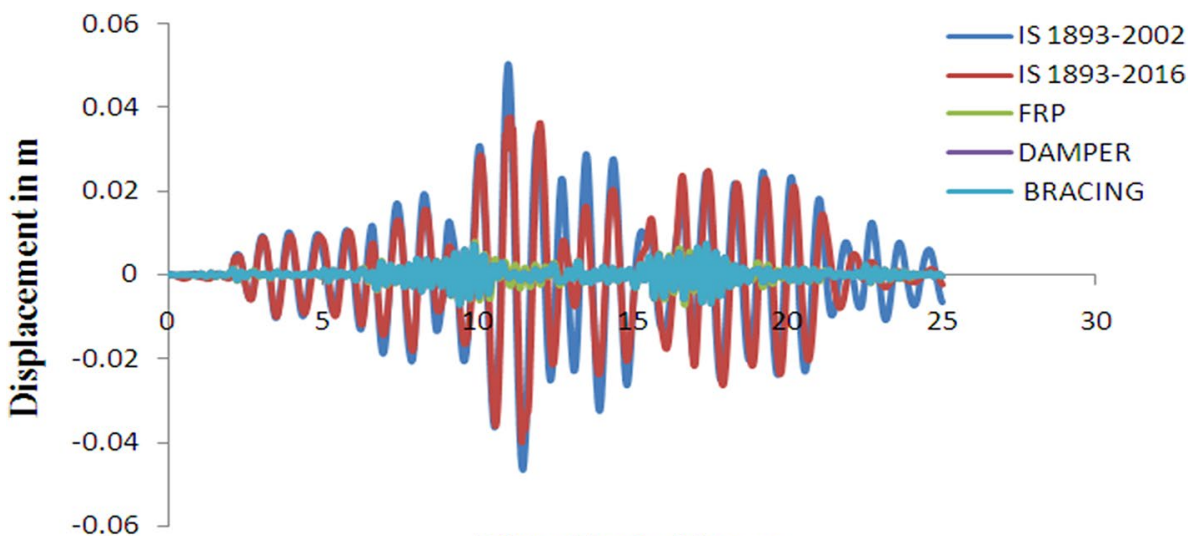

Time Period in sec

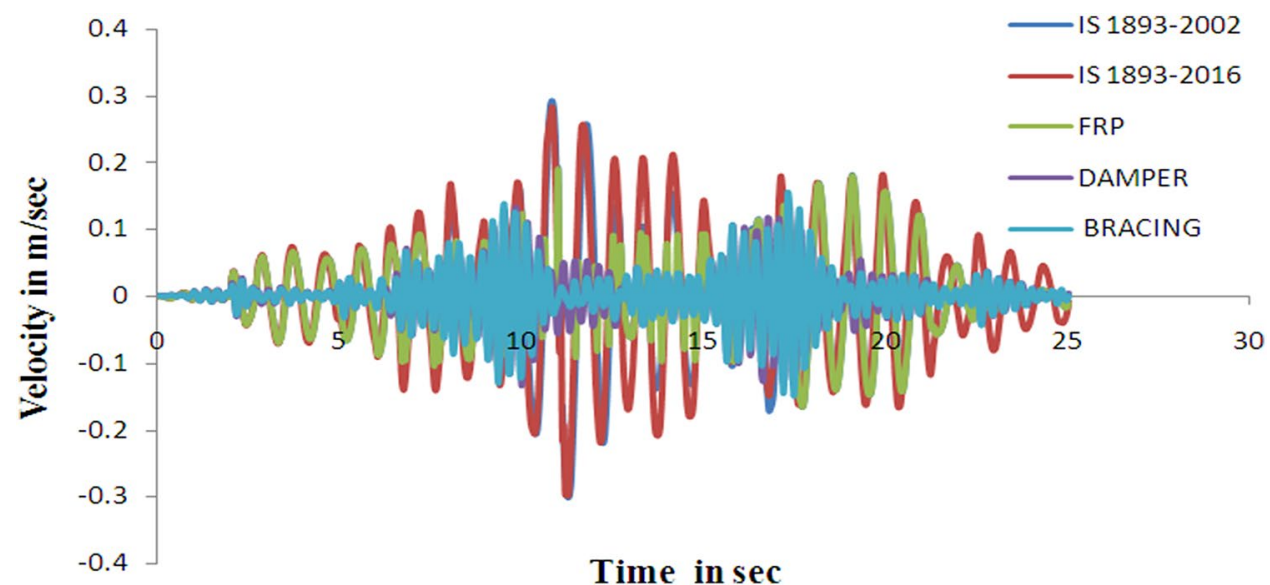


Fig. 14 Comparison between acceleration vs time period

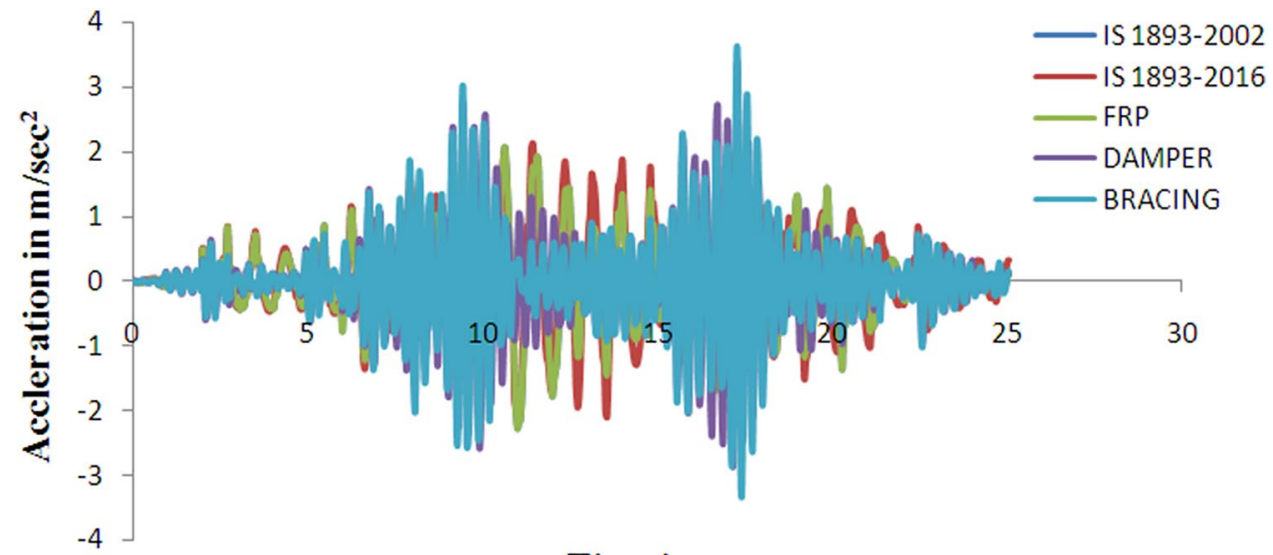

Time in sec

\section{Velocity of ESR}

A graph was plotted taking time as an abscissa and velocity as ordinate for the different types of cases. It was observed that the velocity was less in retrofitting cases than that of the IS code.

Figure 13 clearly shows that the velocity decreased $8.85 \%$ for IS1893-2016, 34.85\% for FRP, $48.39 \%$ for damper, and $54.57 \%$ for bracing with respect to IS $1893-2002$.

\section{Acceleration of ESR}

A graph was plotted taking time as an abscissa and acceleration as ordinate for the different types of cases.

Figure 14, clearly shows that the acceleration increased 6.56\% for IS 1893-2016, $13.63 \%$ for FRP, $69.19 \%$ for damper, and $78.78 \%$ for bracing with respect to IS $1893-2002$.

\section{Findings and conclusions}

An earthquake is one of the most destructive cause recorded in India, resulting in death, devastation, and damage to infrastructure. Earthquakes cause significant damages in the cities of Bhuj, Koynanagar, Khandala port, Ahmedabad, Rajkot, Morbi, etc. Every earthquake leaves a trail of misery by loss of life and destruction. However, it also provides a lesson to human society, particularly engineers and architects for improving designs and construction practices. Based on the research work carried on various aspects related to the development of systematic investigation metrology for condition ranking and strengthening by various retrofitting strategy for existing ESR, the significant findings and conclusions are as follows.

\section{Findings}

1. For systematic investigation, a condition ranking procedure based on AHP has been proposed. DER rating technique was used to find out the condition ranking of ESR at Baramati, Pune, Maharashtra (India).

2. The CI of ESR was found to be very poor, there was extensive deterioration, and the water tank was barely functional. Rehabilitation or reconstruction is required with safety evaluation.

3. In the seismic analysis, the value of story drift exceeds the limit given by IS 456-2000. Hence to maintain the given structure, resisting the seismic force retrofitting of the given structure is necessary.

4. The value of story drift was reduced $9.50 \%, 30.01 \%$, $39.06 \%$, and $44.45 \%$ by the provision of IS $1893-2016$, for FRP, damper, and bracing, respectively, as compared to IS 1893-2002. The lowest drift was observed for the bracing system.

5. After retrofitting, the base shear was increased. The increase in base shear was more pronounced.

6. It has been observed that the time period of higher mode for all cases is quite similar. However, the time period of lower mode tends to differ more.

7. The displacement of water tank was reduced $21.33 \%$, $84.89 \%, 88.28 \%$, and $92.89 .45 \%$ by the provision of IS 1893-2016, for FRP, damper, and bracing, respectively, as compared to IS 1893-2002. The maximum reduction in displacement was observed in the bracing system than all other cases.

8. The velocity was decreased $8.85 \%$ for IS $1893-2016$, $34.85 \%$ for FRP, $48.39 \%$ for damper, and $54.57 \%$ for bracing with respect to IS 1893-2002. 
9. After retrofitting, the acceleration was increased $6.56 \%$ for IS $1893-2016,13.63 \%$ for FRP, $69.19 \%$ for damper ,and $78.78 \%$ for bracing with respect to IS 1893-2002.

\section{Conclusions}

1. From the case study, the DER rating based on the combination of field and visual inspection is found to be more effective to find out condition ranking of ESR without affecting the integrity of the structure.

2. The value of story drift increased the limit of IS. To maintain the given structure and to resist the seismic force, retrofitting of the given structure is necessary. From the analysis, the drift ratio of the water tank is maximum as per IS code as compared to other retrofitting cases.

3. It was also observed that time period for each successive mode decreases as the mode number increases.

4. Implementation of different retrofitting techniques results in a reduction in displacement. This reduction enables the structure to behave almost stiffly.

5. Different retrofitting techniques used in this study result in a decrease in velocity and increase in acceleration.

6. From a case study result of seismic retrofit for the existing elevated water tank, it was confirmed that a relatively simple seismic retrofit method is really effective to keep the tank functional after an earthquake.

\section{Compliance with ethical standards}

Conflict of interest On behalf of all authors, the corresponding author states that there is no conflict of interest.

Open Access This article is distributed under the terms of the Creative Commons Attribution 4.0 International License (http://creativeco mmons.org/licenses/by/4.0/), which permits unrestricted use, distribution, and reproduction in any medium, provided you give appropriate credit to the original author(s) and the source, provide a link to the Creative Commons license, and indicate if changes were made.

\section{References}

Alireza H (2015) Types of dampers and their seismic performance during an earthquake. J Curr World Environ 10(1):1002-1015. https://doi.org/10.12944/CWE.10

ASTM C876-91 (1999) Standard test method for half-cell potentials of uncoated reinforcing steel in concrete. ASTM International, West Conshohocken

Banu D, Barros RCD, Taranu N (2012) Numerical modelling of twoway reinforced concrete slabs strengthened with carbon fiber reinforced polymers strips. In: International conference on experimental mechanics, Porto, Portugal, pp 1-7
Bozorgmehrnia S, Ranjbar MM, Madandoust R (2013) Seismic behavior assessment of concrete elevated water tanks. J Rehabil Civ Eng 1(2):69-79. https://doi.org/10.22075/jrce.2013.8

Fayyadh MM, Razak HA, Ismail Z (2011) Combined modal parameters-based index for damage identification in a beam like structure: theoretical development and verification. Arch Civ Mech Eng 11(3):587-609. https://doi.org/10.1016/S1644-9665(12)60103-4

Gaikwad MV, Mangulkar MN (2013) Comparison between static and dynamic analysis of elevated water tank. Int J Civ Eng Technol 4(3): 12-29

Greimnn L, Stecker J, Rens K (1990) Repair, evaluation, maintenance and rehabilitation research program. Engineering and material division, US Army Construction Engineering Research Laboratory, Champaign

Housner GW (1963) The dynamic behavior of water tanks. Bull Seismol Soc Am 53(2):381-387

IS 13311 (1992) Indian standard code of practice for non-destructive testing of concrete method of test (rebound hammer) (part 2). Bureau of Indian Standard, New Delhi

IS 1893 (2002) Indian standard code criteria for earthquake resistant design of structures (part 1). Bureau of Indian Standard, New Delhi

IS 1893 (2016) Indian standard code criteria for earthquake resistant design of structures (part 1). Bureau of Indian Standard, New Delhi

IS 456 (2000) Indian standard code plain and reinforced concrete-code of practice. Bureau of Indian Standard, New Delhi

Jagadale UT, Kharade R, Nayak CB, Deulkar WN (2019) Experimental investigation for damage evaluation of bridges using piezotransducers. International Association for Computer Methods and Advances in Geomechanics (IACMAG), IIT Gandhinagar, Gandhinagar, pp 47-48

Kakolvand H, Motamedi M (2012) Evaluation of a proposed retrofit technique for unreinforced masonry walls using FEM nonlinear analysis. In: 7th International conference on seismology \& earthquake engineering. Lisbon, Portugal, pp 423-424

Khan I, Franois R, Castel A (2014) Prediction of reinforcement corrosion using corrosion induced crack width in corroded reinforced concrete beams. Cem Concr Res 56:84-96. https://doi. org/10.1016/j.cemconres.2013.11.006

Kumar M (2016) Structural rehabilitation, retrofitting and strengthening of reinforced concrete structures. World Acad Sci Eng Technol Int J Civ Environ Struct Constr Archit Eng 10(1):37-41

Massimiliano F, Alberto M (2017) Base isolation for seismic retrofitting of a multiple building structure: design, construction, and assessment. Hindawi Math Probl Eng 2017:1-24. https://doi. org/10.1155/2017/4645834

Mishra A, Singh M, Srivastava A (2015) RC Jacketing on RCC frame of overhead water tank using results of non- destructive testing-a case study. In: 6th International conference on structural engineering and construction management 11th-13th December 2015, Kandy, Sri Lanka, pp 44-52. http://dl.lib.mrt.ac.lk/handl e/123/11546

Morfidisa K, Kostinakis K (2019) Comparative evaluation of MFP and RBF neural networks' ability for instant estimation of R/C buildings' seismic damage level. Eng Struct 197:1-19. https:// doi.org/10.1016/j.engstruct.2019.109436

Motamedi M, Nateghi-A Fariborz (2018) Study on mechanical characteristics of accordion metallic damper. J Constr Steel Res 142:6877. https://doi.org/10.1016/j.jcsr.2017.12.010

Nayak CB, Thakare SB (2016) Retrofitting and rehabilitation of elevated water tank after investigation of corrosion status by using nondestructive techniques. In: International congress on computational mechanics and simulation, IIT, Bombay, pp 1244-1247

Nayak CB, Thakare SB (2017) Investigation of corrosion status in elevated water tank by using nondestructive techniques in Baramati 
region. In: International conference on construction real estate, infrastructure and project management, NICMAR, Pune, pp 1-17

Nayak CB, Thakare SB (2017b) analysis and retrofitting of elevated water tank in pune district: by Uttarkashi earthquake. J Eng Technol 6:201-211

Nayak CB, Thorat NS, Thakare SB (2018) Corrosion impact analysis on residual life of structure using cathodic technique and algor simulation software. Eng Struct Technol 10(1):18-26. https://doi. org/10.3846/est.2018.1468

Nayak CB, Walke S, Kokare S (2019) Optimal structural design of diagrid structure for tall structure. In: ICRRM 2019—system reliability, quality control, safety, maintenance and management, pp 263-271. https://doi.org/10.1007/978-981-13-8507-0_39

Omidinasab F, Shakib H (2012) Seismic response evaluation of the $\mathrm{RC}$ elevated water tank with fluid-structure interaction and earthquake ensemble. KSCE J Civ Eng 16(3):366-376. https://doi. org/10.1007/s12205-011-1104-1

Ortega NF, Robles SI (2016) Assessment of residual life of concrete structures affected by reinforcement corrosion. HBRC J 12:114 122. https://doi.org/10.1016/j.hbrcj.2014.11.003

Poursaee A, Laurent A, Hansson CM (2010) Corrosion of steel bars in OPC mortar exposed to $\mathrm{NaCl}, \mathrm{MgCl}_{2}$ and $\mathrm{CaCl}_{2}$ : macro- and micro-cell corrosion perspective. Cem Concr Res 40:426-430. https://doi.org/10.1016/j.cemconres.2009.09.029
Sasmal S, Ramanjaneyulu K (2008) Condition evaluation of existing reinforced concrete bridges using fuzzy based analytic hierarchy approach. Expert Syst Appl 35(3):1430-1443. https://doi. org/10.1016/j.eswa.2007.08.017

Sohail MG, Laurens S, Deby F, Balayssac JP (2015) Significance of macro-cell corrosion of reinforcing steel in partially carbonated concrete: numerical and experimental investigation. Mater Struct 48(1):217-233. https://doi.org/10.1617/s11527-013-0178-2

Vesmawala GR, Kodag PB (2017) Investigation of GFRP strengthened RC non-slender columns under eccentric loading. Građevinar 69(9):831-840. https://doi.org/10.14256/jce.1591.2016

Wankhade RL, Landage AB (2013) Non-destructive testing of concrete structures in Karad Region. Procedia Eng 51:8-18. https://doi. org/10.1016/j.proeng.2013.01.005

Zhu W, François R (2013) Effect of corrosion pattern on the ductility of tensile reinforcement extracted from a 26 year old corroded beam. Adv Concr Constr 1(2):121-136. https://doi.org/10.12989 /acc2013.01.2.121

Publisher's Note Springer Nature remains neutral with regard to jurisdictional claims in published maps and institutional affiliations. 